\title{
Early Marriage among Sasak Boys \\ in Rural North Lombok
}

\author{
Lisa Colquhoun, Pamela Nilan \\ University of Newcastle, Australia \\ lisa.m.colquhoun@gmail.com | pamela.nilan@newcastle.edu.au
}

\begin{abstract}
Child marriage remains a pattern in parts of Indonesia despite recent legislative attempts to ban the practice. Previous studies of the phenomenon have primarily concerned girls. Against that research trend, this article seeks to shed light on early marriage among Sasak boys in rural north Lombok, West Nusa Tenggara. It draws on the narratives of six young Sasak men who were married during their mid-teens. Our analysis focusses on the sustained and potent influence of traditional cultural and religious practices, gendered norms of romance and sexual conduct, and normalised early youth transitions in a context of inter-generational poverty.
\end{abstract}

KEYWORDS: Youth | Masculinity | Sasak | Lombok | Early Marriage.

\section{PREFACF}

In the long history of the Indonesian archipelago, marriage and parenthood were, and remain, transition points marking definite, unambiguous entry into adulthood (see Bennett 2005, 2015; Nilan 2008; Parker 2008; Naafs 2013). When total life expectancy was very low and family size very large, early to middle adolescent marriage among girls in Indonesia was common. In recent times, however, that cultural pattern has shifted. Life expectancy has increased, infant mortality rates have fallen, and so have family sizes. Public health care, family planning, universal literacy, rapid economic growth, human rights legislation and improved nation-wide communications have all rendered child marriage much less acceptable, at least in urban, middle-class and prosperous rural areas (Sukmayeti 2019). In September 2019, Indonesia's Constitutional Court raised the legal marriageable age for women from 16 to 19 , bringing it in line with the age for men. That move followed lengthy public debate surrounding the issue of early marriage - and ensuing early parenthood - as a violation of children's rights. ${ }^{1}$ Understandably, given the negative health impact on girls, the focus of debate and, of extant relevant research, has tilted almost entirely towards "child brides" (see Lestari 2001; Widyoningsih 2011; Marshan, Rakhmadi and Rizky 2013; Bennett 2014; Rumble et al 2018; Beta and Febrianto 2020). Moreover, studies have most often focussed on girls marrying older men; yet, in impoverished rural north Lombok where early marriage is prevalent (Bennett 2014), the husbands of young Sasak brides are often also children themselves.

\section{Sasak Boys in Context}

There is great socio-economic contrast between urban and rural Indonesia, and marriage patterns follow that difference. For example, national capital Jakarta is Indonesia's "pace-setter in delayed marriage" (Jones 2002: 228. See also Qibthiyyah and Utomo 2016). A delayed marriage pattern follows not only rapid economic growth but the progressive decline of tradition and social structures - a process variously described as "detraditionalisation" (Heelas et al. 1996) and "disembedding" (Giddens 1991). In Jakarta and other urban centres of Indonesia, marked political, economic and cultural change 
have chipped away at past traditions, resulting in later age of marriage for both sexes (Nilan 2008) although this trend seems to have become more uncertain in recent times (Qibthiyyah and Utomo 2016). The pace of change is, nevertheless, much slower in places like rural north Lombok, where poverty and inadequate telecommunications infrastructure limit villagers' exposure to the force of cultural transformation. There, adat and local interpretations of Islam maintain a sustained and potent influence on village social practices, including marriage (see Buttenheim and Nobles 2009).

Lying west of Bali, the arid island of Lombok is known as the "land of a thousand mosques". While most Sasaks in the rural north describe themselves as orthodox Muslim, or Waktu Lime (“[pray] five times"), some identify as Wetu Telu ("[pray] three times"). They practice a syncretic form of Islam entwined with Hindu and indigenous animist beliefs. Wetu Telu are often perceived as less educated and more "traditional" than their Waktu Lime neighbours (Bennett 2005). Of rural north Lombok households, around one third live in absolute poverty (BPS 2013; WFP 2013). The region records the lowest education levels, literacy rates and gross domestic product (GDP) per capita in Lombok and the West Nusa Tenggara province more widely and, at just 61.72 years, the shortest average life expectancy in all of Indonesia (BPS 2013). Unemployment there is high, and cash income is low and irregular. Villages depend on subsistence livelihoods highly susceptible to changes in rainfall and weather, such as farming and fishing. Despite efforts to develop "quality" tourism across north Lombok, local people profit little given that the tourist industry is largely under the control of foreigners and nonSasak Indonesians (Kamsma and Bras 2000). For the local Sasaks, who bear the brunt of poverty and low development, this continues a long history of social and economic marginalisation and domination by "outsiders" (see Van der Kraan 1975; Ricklefs 1993; Brown 2003; Clegg 2004). Certainly, the best hope for most young Sasak males is to pick up casual seasonal work at the low-paid edges of the tourism sector.
We argue that the marital trajectories and decision-making of Sasak boys in rural north Lombok are shaped by a synthesis of Islam, adat, endemic poverty and marginalisation. First, Quranic teachings on the "natural" role of men (kodrat pria) underpin dominant local gender norms to confer full masculine and social status only on married males, putting pressure on Sasak boys and men to marry. That pressure is compounded by local indigenous constructions of romantic love and Islamic moralities surrounding premarital sex, which cast marriage as the only legitimate place in which to express sexual desire. Second, the experience of poverty drives Sasak boys out of school and into the lowwage labour force early, accelerating transition to the "adult" role of husband and, thereafter, father. Third, local Islamic and adat marriage norms allow underage Sasak boys to marry outside the state legal system and quickly achieve adult masculine and social status. In the short-term, that effectively compensates for their marginal position and shortfall in material resources; however, we suggest that, in the long term, it reinforces the cycle of inter-generational poverty endemic to the region.

\section{METHODS}

The data here comes from a longitudinal ethnographic study of young fathers in an impoverished north Lombok village (desa). This involved three separate waves of data collection between November 2017 and September 2019. The first wave of data collection was conducted over a three-month period and focussed on the young fathers' transitions to early fatherhood and their current lived experiences of fatherhood, including their transitions to and experiences of early marriage. Subsequent waves were each conducted over a three-week period and focussed on capturing temporal changes in the young fathers' experiences of fatherhood, including changes within their marriages.

Quotes in this article were drawn from interviews with six young Sasak men from two neighbouring hamlets (dusun) about their own lived experiences of early marriage, as told to the first author. Each informant was younger than 18 at the time of mar- 
riage and three went on to father a child before they were 18. One informant became divorced during the course of the study. Insights on local marriage patterns and customs were also gathered by the first author from observations made during two wedding ceremonies and from interviews with other desa residents.

Interviews with the six young grooms were conducted, where possible, in Bahasa Indonesia, with a Bahasa Sasak translator assisting when required. Most interviews took place either inside the homes of the young grooms or in a berugaq (neighbourhood outdoor pavilion). The interviews were 60 to 90 minutes long and recorded either on an iPhone or through detailed notetaking. Transcripts and fieldnotes were coded and analysed using a contextualised thematic approach (see Liamputtong 2019).

\section{FRAMEWORK}

This article draws on Raewyn Connell's (1987) theory of hegemonic masculinity as an interpretive framework to explain the continuation of early marriage in Lombok as a practice which not only subordinates girls and young women, but which in the end, subordinates poor, marginalised boys and young men. We argue that Sasak boys achieve some measure of hegemonic masculinity through early marriage - and, thereafter, early fatherhood - yet this "win" for adult male patriarchal status also ties them, their wives and offspring into an adverse cycle of endemic inter-generational poverty.

In principle, hegemonic masculinity is positioned at the apex of the hierarchy of all forms of masculinity and, indeed, of femininity. In any context, it is the culturally and currently most venerated

Table 1

Details of Informants

\begin{tabular}{|l|l|l|l|l|}
\hline Name & \multicolumn{1}{|c|}{ Occupation (Industry) } & Age at Marriage & $\begin{array}{l}\text { Age at First Birth of } \\
\text { Child }\end{array}$ & Level of Education \\
\hline Wira & $\begin{array}{l}\text { Plantation worker } \\
\text { (seasonal agriculture and } \\
\text { farming) }\end{array}$ & 17 & 19 & SMA $^{1}$ \\
\hline Modyn & $\begin{array}{l}\text { Casual labourer (con- } \\
\text { struction) }\end{array}$ & $\begin{array}{l}16 \text { (divorced at } \\
20)\end{array}$ & 17 & None \\
\hline Hafid & $\begin{array}{l}\text { Casual dishwasher } \\
\text { (tourism) }\end{array}$ & 17 & 18 & SMP $^{2}$ \\
\hline Sapriadi & $\begin{array}{l}\text { Casual labourer (con- } \\
\text { struction) }\end{array}$ & 16 & 20 & None \\
\hline Rudin & $\begin{array}{l}\text { Warung operator (retail) } \\
\text { (tourism) }\end{array}$ & 15 & 16 & SMA $^{3}$ \\
\hline
\end{tabular}

Notes:

1. SMA - Sekolah Menengah Atas - Senior High School

2. SMP - Sekolah Menengah Pertama - Junior High School

3. SD - Sekolah Dasar - Primary School 
sense of what it means to be a man Hegemonic masculinity is an ideal which requires the achievement of not only successful (heterosexual) reproduction, familial patriarchy and providership, but also of solid and sustained economic status that encodes power over poorer, subordinate men. Synonymous not with working class machismo but, rather, with middle-to-upper class male power and authority, hegemonic masculinity is a model of manhood which is unattainable for men on the lower rungs of the class ladder (Dowd 2010; Connell and Messerschmidt 2005). Yet at the same time, hegemonic masculinity is not the same everywhere. For grasping specific cultural forms of hegemonic masculinity, the question of place, of geographical location, is paramount.

The exercise of conceiving a hegemonic form of masculinity in Indonesia is inherently problematic "because a country as huge and heterogeneous as this does not have a single narrative" (Vickers 2005: 3). While various scholars have gestured to the figure of the Bapak as the most recent culturally exalted model of masculinity (Clark 2010; Izharruddin 2017), the relevance of Bapakism to contemporary young males in rural north Lombok is dubious. The Bapak ideal is anchored in the figure of the aristocratic Javanese patriarch ruling over family, community, business and nation-state. Personified by Suharto during the New Order, it is an historical and geographically-distant construct with seemingly little influence on the lives of Sasak boys in rural north Lombok today. Still, the ability of Indonesian boys and men to enact any local form of hegemonic masculinity is very much contingent on ethnicity and socioeconomic status (See Nilan, Demartoto and Wibowo 2013). After all, hegemonic masculinities everywhere always and unavoidably intersect with other such inequalities (Messerschmidt 2018). Ian Wilson (2012) points out that as resources, opportunities and affluence become more and more inaccessible to socially and economically marginalised young men across Indonesia, they increasingly prize other means for demanding respect and achieving male social status with a minimum of resources. In impoverished north Lombok, this is what early marriage and fatherhood achieve.

\section{EARLY YOUTH TRANSITIONS}

The life course for young Sasaks in north Lombok continues to be structured by cultural and religious expectations about achieving adulthood through marriage and parenthood. Adult male status should be additionally marked by engagement in paid work. However, given that the parent-son relationship is characterised by interdependency throughout the Sasak life course, paid work, no matter how insecure, signifies not so much a means to achieve autonomy and independence from one's natal family but, rather, preparedness for the "adult" role of husband and father. In the words of one young groom, Wira, "a man must work first before deciding to get married and have children, because he will become the breadwinner in his family - that is his responsibility." It is clear that having a job (of any kind) is considered a precondition for marriage. Income enables a Sasak man - or, indeed, boy - to assume the traditional breadwinner role (pencari nafkah) expected of them within marriage and parenthood (see Elmhirst 2007). That directly aligns with Quranic teachings on the "natural" role of men.

Sasak boys in north Lombok tend to enter the labour force early, driven by poverty and the relatively high cost of post-primary schooling (see Suryadarma, Suryahadi, and Sumarto 2006). As Utomo et al (2014: 1193) explain in their study of Indonesian early school leavers, "if the child could be earning money in paid labour instead of being enrolled in school, then continuing in school presents a potential loss of income for the family." That emerged as the primary rationale for the low educational attainment and early labour force entry of the six young grooms here. Following an average of just six years of schooling, the grooms first entered the labour force around 12 years, taking advantage of employer preference for cheap child labour. There is a common pattern of premature school exit and child labour across north Lombok, in the local context of harsh poverty, low overall life expectancy and a high infant mortality rate (Hay 2007).

For the young grooms, early workforce entry meant that, despite their extreme youth, they felt ready for marriage as the taken-for-granted next step 
in what might well be a total life journey of six decades. Indeed, a quarter of their lives might have already passed by the time of their early marriage. As Modyn explained, "I had a job when I was still young [16], already searching for money when I was still young. So, when I met my wife, I was ready [to get married] because I had something to give to her and our children." Likewise, for Rudin: "I was only 16 but I had already been working for three or four years, so I was more mature than my age and I already had some money... I felt really ready to marry." Supported by local cultural and religious understandings, the young grooms' perceptions of marital readiness were predicated more strongly on engagement in paid work and capacity to provide for a wife and children than on biological age. Low educational attainment and early labour force participation thus accelerate Sasak boys' self-perceived readiness for marriage.

\section{YOUNG LOVE AND COURTSHIP}

Local youthful constructions of romantic love are critical to understanding the decisions of Sasak boys regarding spouse selection. In contrast to other Indonesian cultures that favour arranged child marriage, Sasak society is widely accepting of self-selected marriage based on love and mutual attraction (Grace 2004). For the six young grooms, romantic love - cinta - was the determining factor in their selection of a wife. Cinta, as constructed by the grooms, reflects the fatalistic orientation indigenous to Lombok (Krulfeld 1966). It is represented as a seemingly irrational attraction between lovers - an overwhelming yet involuntary feeling accompanied by uncontrollable and often-unsettling physical symptoms. When recounting their experiences of falling in love with their now-wives, the young grooms spoke of feeling sakit (ill), pusing (dizzy) and mabuk (drunk). They recalled loss of appetite, insomnia, confusion, lack of concentration, and inability to think of anything or anyone else but their love interest. These affective and bodily experiences were understood as sure signs of the cinta upon which their early marriages were founded. Each of the young grooms married within four months of meeting their wives-to-be; some within a matter of days. For all but one, this was their first ever experience of romantic love.

There is a general tendency for young people in the north Lombok villages to marry the first person with whom they fall in love. That pattern was also observed in rural east Lombok (Grace 2006). Part of the explanation lies in the Sasak belief in pre-destination. Several young grooms spoke of having found their jodoh (true match), described by Bennett (2005: 58) as "akin to the notion of love between soulmates ... determined by destiny and spiritual compatibility." For instance, at the age of 17 Hafid married his first love after a one-week courtship. He recalled that, "she wanted to get serious with me, so I agreed [to marry her] because I thought she was the jodoh that God gave me." If he had delayed his marriage, Hafid explained, he would have risked losing his soulmate and the sudden, God-given love they shared because, he said, "jodoh doesn't come twice."

The risk or fear of "losing" their love interest - or soulmate - was frequently cited as one reason for not waiting until they reached the legal age before marrying. That fear was expressed almost always in reference to other men. Traditional courtship practices in Lombok permit unmarried Sasak females to entertain as many suitors as they please (see Bennett 2005), so Sasak boys often find themselves in uncomfortable competition with other males for the attention of a girl. To lose her to another suitor is injurious not only to young hearts but to masculine pride. The risk is resolved only by the promise of marriage. For Sasak boys, courtship thus becomes a race to be the first among possible multiple suitors to gain a girl's agreement to wed. Once her agreement is secured, then the boy's pathway towards achievement of "hegemonic" masculine status is affirmed in the eyes of the community.

\section{MORAL RISK OF PREMARITAL SEX}

Sasak boys' decisions on the timing of marriage are also strongly influenced by strict social and religious norms of sexual conduct, which discourage 
them from delay. Each of the young grooms very much desired sex with the girl they were courting. However, this is a moral and religious taboo (haram) outside marriage. Within Islamic legal frameworks, any sexual activity which takes place outside marriage - zina - is considered unlawful and thus punishable under Islamic law. To legally have sex with their love interest, the young grooms were therefore required to marry first. Speaking of the prevalence of early marriage in his village, one local man explained,

It is usually because of sex, because we're not allowed to have sex before marriage, so many people here marry very young and very quickly, after one month, two months, sometimes just one week. They might fall in love with some girl and want to have sex with her, so they must hurry up and marry first so that they can avoid zina.

While it is girls and women who are most often condemned for committing zina (Bennett 2005), Sasak boys are not invulnerable to public censure. This was evident in an episode of violence witnessed by the first author during fieldwork in 2017. It took place following the discovery of a young Sasak couple embracing and kissing at a local beach. The boy, barely in his teens, was subjected to a vicious stone-throwing attack by a group of six older men - presumably the brothers and older male relatives of one member of the pair. Surveillance of premarital sexual relations in north Lombok is not, however, limited to families; local authorities are also responsible for regulating zina. Local stories abound about young, unmarried lovers caught in compromising situations by police. In gubuk pantai (beach huts) or beneath the coconut trees, young couples are said to meet in darkness. If found, they are apprehended and taken to the sub-district police station, where they are lectured on morality. Their parents are notified. The implications are severe, particularly for girls and young women but also for boys who are likely to be reprimanded with physical punishment in the home. Usually, the family of the boy will be forced to pay a significant "fine" to the girl's family to compensate for any potential damage to her reputation, causing financial stress and conflict between the boy and his family. Often, the couple will be pushed to marry as soon as possible.

As the only legitimate place in which to act on sexual desire, transition from courtship to marriage is very frequently expedited by young Sasak couples in love. A quick adolescent marriage avoids violation of zina and its repercussions. Regarded as far from a misfortune by young grooms, early marriage affords Sasak males a socially-sanctioned opportunity to express their heterosexuality and to reproduce, both of which are fundamental tenets of hegemonic masculinity (see Townsend 2002; Mansfield 2006). For boys who have limited capacity and resources to accumulate masculine capital in other ways, early marriage is an easy way to affirm their manhood. Delaying marriage would not only risk committing zina, but call their manhood into question. 15-year-old groom Hendy summed up the key dilemma: "In our culture, if you're not married, you can't have sex, you can't have children. It means you are not yet a real man." Through marriage, Sasak boys ensure public knowledge of their (hetero)sexual activeness and commitment to fatherhood, thereby guaranteeing their status as a "real [adult] man."

\section{SPONTANEOUS ELOPEMENT}

Local marriage customs reflect the continued influence of adat on village practices. Although no longer a mandatory precursor for marriage as it had been for Sasaks in previous generations (Bennett 2005), the customary practice of spontaneous elopement, meraqiq, remains the norm and is tightly bound to local ideals of masculinity. All but one of the six young grooms had gone through it. Eschewing the favoured tradition, one young groom, Rudin, heeded the request of his wife-to-be by following the modern and more respectable path of seeking parental permission to marry. In doing so, he was seen to have cowered from the meraqiq challenge, which threatened his masculine image as the would-be-groom and was likely a cause of mockery among his peers. Maintaining a fiction of bride capture (see Krufield 1986), in merariq the boy bravely "kidnaps" the girl from her natal home, seemingly right under the noses of her watchful parents. Following the feigned kidnapping, the couple comme- 
nces a daunting yet exhilarating journey to their pre-determined pasebon (temporary hideout). This is usually the boy's natal home, a hotel or the house of a friend or relative. In courageously and successfully avoiding the risk of pursuit, capture and punishment by the girl's family, whether real or imagined, the couple's arrival at the pasebon is viewed as proof of the boy's courage and skill. For 16-year-old groom Sapriardi, "that was the moment I felt like I had become a man."

From the pasebon, the couple call on a trusted friend or relative of the young man to notify the girl's family of their elopement. Often, the girl's family will have already reported her disappearance to the head of village (Kepala Dusun); her empty cupboards providing evidence of her capture. In the case of child couplings, the boy's family is usually also unaware of the marriage agreement between the young couple and will need to be notified of the elopement. Of the five young grooms who had conducted meraqiq, only two informed their families beforehand. Once both families are made aware, the elopement is formally announced by way of an official letter - the sejati selabar - delivered to the girl's family. The Kepala Dusun on both sides will then invite the two families to meet to deliberate on the best course of action to ensure, as quickly as possible, consummation of merariq through marriage.

Almost every couple goes on to marry following meraqiq. A marriage is only contested by families if the union is in conflict with their interests or they are unable to come to agreement on the pisuke (bride price). This is most common in meraqiq between people from different class backgrounds (Bennett 2005). Age is very rarely a reason for contesting a marriage (Bartholemew 2001). Failure to secure marriage following meraqiq would be detrimental to the reputations and future marriage prospects of both parties in a young couple and a source of great shame to their respective families (Sukmayeti 2019). For would-be grooms in particular, it is also a major affront to their masculinity. Such was the case for one poor, young fisherman encountered by the first author during fieldwork. Following his return from meraqiq, the wealthy family of his would-be bride re- pudiated the intended marriage, much to his despair and humiliation. In his effort to defend his manhood - as well as to recover his family's pride and dignity in the community - the boy eloped with and married another (lower class) girl only two weeks later. In short, it is in the interests of both sets of families to sanction an intended marriage, regardless of the ages of the prospective bride and groom. Thus, the adat practice of meraqiq is a conduit for child marriage.

\section{RELIGIOUS AND SEGRET MARRIAGES}

In rural north Lombok, greater value is placed on the legitimacy of marriage within an Islamic framework than within the state legal system, so the national legal prescription of marriageable age is routinely ignored. Islamic texts do not specify a minimum legal age for marriage, requiring only that both members of couple are judged sexually mature and of sound judgement (Qur'an 4:6, 24:31, 24:58-59). Boys and girls in their early teens may marry if the religious courts deem them sufficiently mature. This is, of course, highly subjective. Indeed, judges in religious courts across north Lombok - often at the behest of the couple's respective parents - are inclined to take meraqiq itself as indicative of maturity. The great fear is that the couple will engage in the sin of illicit premarital sex (Nurlaewati 2010). This was confirmed by 16-year-old groom Modyn: "they usually approve [of underage marriages] because they worry that the couple will sin if not approved... Whatever is their judgement, the couple will still be in love anyway, so it is better to just let them marry."

Fundamental to all Sasak marriages is the Islamic marriage contract, akad nikah. In rural north Lombok, akad nikah is formalised either at the natal home of the bride or at a local mosque, usually within days of a couple returning from meraqiq. An imam (religious leader) or kadhi (religious official) recites the marriage service, outlining the rights and responsibilities of a husband and wife within marriage, to which the couple must verbally agree. The groom and his soon-to-be father-in-law are then required to sign the contract, which details the agreed pisuke, thereby solemnising the marriage. As per the contract, the groom will also present his new wife 
with the maskawin, or mahar (bridewealth). This comprises a sum of cash and/or a gold ring of a certain weight, together with a Quran and prayer accessories, all determined in advance by the bride. If merariq is a test of a Sasak boy's bravery, then maskawin is a test of his ability to provide for his wife and future children.

Perceived validity of marriage in north Lombok Sasak society hinges on the Islamic akad nikah itself, not on whether the marriage is registered officially - either with the Office of Religious Affairs or the Office of Civil Registry. Thus, as Platt (2017) observed, state registration of religious marriage is a low priority for underage Sasak couples. Many couples in their teens enter into an unregistered akad nikah - or nikah siri (secret marriage). Indeed, north Lombok is reputed to have among the highest incidence of nikah siri in all of Indonesia (Abdullah and Djumardin 2017). Of the six young grooms here, the marriages of four were secret - nikah siri. The remaining two grooms illegally falsified their birthdates in the required documents to register their marriages officially, allowing any future children to access the beneficial citizenship rights that are available only to children born in (registered) wedlock. This is, however, a costly tactic requiring payment of small bribes and "hush money" to a range of local actors. It is, of course, possible for underage couples to legally obtain postdated recognition of an unregistered religious marriage (isbath nikah) once they have reached the legal marriageable age. However, the expense of this, together with the illegitimate legal status of any children born prior to the isbath nikah ${ }^{2}$, stand to deter couples from taking this path. Instead, the default cultural position is to elevate Islam as the final arbiter of "legitimacy." For example, justifying his decision not to register his (now defunct) marriage, young groom Modyn, explained, "in Islam, documentation or marriage certificates are not important. The akad nikah is enough. So, my marriage is valid."

\section{SERIAL MARRIAGE AND DIVORGE}

Serial marriage is very common in rural north Lombok, where divorce carries much less stigma than never married. It is preferable for both sexes to engage a cycle of marriage and divorce -kawin-cerai (Smith 2014; Platt 2017) - than to remain unmarried. Of the six young grooms, five were still married in early 2020; one, Modyn, is divorced. While for each of the grooms the marriage was their first, the wives of two - Sapriadi and Wira - had been married previously. Reflecting on his wife's status as a divorcee, Sapriadi claimed, "it's no problem for me. It's really normal here. Sometimes people marry three or five times, no worries." There is almost a cultural expectation that a first marriage, particularly a young first marriage, will not last. Once the initial romantic infatuation wanes, young couples are likely to find themselves incompatible or bored. For example, Wira explained of his wife, "she was bored with her [first] husband. There was no feeling of love there anymore, so she left him and went back to her family. Three times she did that, so they had to divorce."

Threatening to divorce one's spouse, either on three separate occasions or by repeating the statement "I divorce you" three times in a single declaration, is known as "triple talaq". Under Islamic law, triple talaq dissolves a marriage instantly. Modyn's marriage ended abruptly when he declared triple talaq during an argument with his wife. Although Modyn admitted that at the time he had not intended to end the marriage, his pronouncement of triple talaq was overheard by others living in the gubuk (small patrilineal household grouping). It meant that the marriage was immediately terminated within Islamic frameworks and in the eyes of the community. According to an older local man, this custom explains the high rate of divorce among young married couples, since "young people are quick to anger, quick to say [triple talaq] without thinking too much beforehand." Second and subsequent marriages, he suggested, tend to last longer because couples have mastered greater control of their emotions in maturity.

Young first marriages are considered not only more susceptible to breakdown due to emotional immaturity, but also to infidelity. Sapriadi's wife divorced her first husband for that reason and Sapriadi 
himself confessed to engaging in extramarital relationships - pacaran lagi - during their marriage. While he said his wife was unaware, others living in his gubuk were privy to his indiscretions. Justifying his infidelity, Sapriadi explained that his wife was his first sexual partner and, as a young, hot-blooded male, he was "naturally" curious to see "what else was out there." As Platt (2012) observed, even though it is taboo, Sasak boys and men tend to view pacaran lagi as instinctive for men. That reflects dominant local constructions of male sexual desire as something which is physically difficult to restrain. While men often go to great lengths to hide their infidelity, many, like Sapriadi, freely admit to it. Certainly, there is greater tacit acceptance of (male) extramarital sex than of premarital sex in rural north Lombok, despite both falling within the bracket of zina. The only real repercussion for engaging in pacaran lagi is the possibility of divorce which is, indeed, normalised within the context of kawin-cerai and expected of first marriages anyway.

\section{EARLY FATHERHOOD}

Discussion and debate surrounding child marriage and parenthood in Indonesia often attribute the phenomenon to unplanned, premarital pregnancy. This is not, however, the prevalent pattern in rural north Lombok where the majority of young $\mathrm{Sa}$ saks are married at the time of conceiving their first child (Bennett 2005). It is expected that Sasak couples have children as soon as possible after marriage. After all, having children is understood locally as the primary function of marriage in Islam and at the heart of both men's and women's "natural" roles ( $\mathrm{ko}^{-}$ drat pria/wanita). This is despite Quranic injunctions against reproducing conditions of poverty (see Surah An-Nisa: 9). For example, during an akad nikah ceremony attended by the first author, the presiding imam jestingly urged the newly married couple to begin trying for a baby that very night. He instructed the young groom, "your job now is to get your wife pregnant." Indeed, all six young grooms tried to conceive a child immediately following their marriages. Four were successful within six months; a source of great pride. Rudin, recalled the moment he learned of his wife's pregnancy five months after their marriage. He had just turned 17: "When my wife told me she missed her period, I felt very happy, very proud to know that I could make a baby."

For Sasak males, fatherhood is the ultimate masculine status marker. If a newly married groom is unable to conceive a child quickly, he is perceived in the community as defective and not "manly" (jantan); his failure to demonstrate fertility engendering feelings of masculine inadequacy and shame. This was the case for 16-year-old groom, Sapriadi, who was mortified by the three years it took to conceive a child:

I saw my friends and other couples, it was easy for them to have a child. People were always asking me, "Why don't you have a child yet?" I felt sick when people asked me about it, sick in my heart. I felt like I wasn't manly, like I wasn't a real man, because three years and I couldn't make my wife pregnant. I was ashamed, stressed out. I remember feeling very relieved when my wife got pregnant. "Yes! I am a real man!" I said it like that. I am a real man! I don't have a problem! I was proud to tell everyone I saw.

Hegemonic ideals of masculinity, tied to Islamic discourses of kodrat pria, discourage Sasak males from delaying fatherhood following marriage, irrespective of age. Thus, a very young groom is likely to become a father while still technically a child himself. That was the experience of Modyn, Hendy and Rudin. Notably, while their early entry into fatherhood cemented their adult male status in the community, it confined their young families within the inter-generational cycle of poverty and marginalisation endemic to rural north Lombok. As previously mentioned, children born in underage marriages are considered to be illegitimate within the state legal system, attracting the status of anak luar kawin (child born out of wedlock). That is a highly stigmatised status with severe implications for the futures of those children, including possible lack of access to education and health services, citizenship and inheritance rights, and formal sector employment. 


\section{CONCLUSION}

The recent decision of Indonesia's Constitutional Court to raise the legal marriage age for women is an important step to curbing child marriage across the archipelago. However, as the example here of Sasak boys in north Lombok shows, that alone is not enough. Despite long-standing national law to the contrary, Sasak boys have continued to marry in their mid-teens, pointing to more complex factors at work. Our findings suggest that local adat and Islamic marriage norms and practices take precedence over distant legislative directives from Jakarta, providing ample opportunity and legitimation for underage marriage outside the state legal system. At the same time, indigenous constructions of romantic love and traditional courtship practices, together with the intense social surveillance and public censure of premarital sex, discourage Sasak boys from delaying marriage. To delay marriage is to run the risk of violating zina or, perhaps worse yet, losing one's predestined love interest to another man. Where localised Islamic and adat norms render marriage as a "fluid and flexible act that can be entered into spontaneously and just as easily undone" (Platt 2017: 43), these risks have greater impact on the reputations and status of Sasak boys than does the potential dissolution of an underage marriage.

Perhaps a larger issue, however, is not the marriage norms per se but, rather, gender norms which confer adult masculine status to married males and, especially, to married fathers regardless of biological age. Poverty and marginalisation play a key role in upholding these two markers - marriage and fatherhood - as a compensatory strategy. Their achievement allows Sasak boys to offset their shortfall in material resources and status by marrying and becoming fathers while still young. That differs from the compensatory strategies of boys and young men in similarly impoverished circumstances - albeit in mostly urban settings - elsewhere in Indonesia who might perhaps draw on the "compelling discourses of hyper-masculinity" propagated through the global popular media to construct alternative, "counter-hegemonic" youthful masculinities to compensate for their own lack of resources (Nilan 2009: 339; see also Clark 2004; Scherer 2006). In the sparsely-populated, subsistence-level villages of rural north Lombok, the telecommunication infrastructure is much less adequate than in Indonesia's urban centres, while Islam and adat remain far more potent forces. In that context, the exposure to and influence of global discourses of hyper-masculinity on local constructions of manhood is limited. Certainly, Sasak boys in rural north Lombok continue to draw primarily on religious and traditional cultural values and practices to achieve a locally legitimate model of adult masculinity.

Through early marriage and, thereafter, early fatherhood, Sasak boys can quickly achieve adult masculine and social status beyond the limitations of endemic poverty, brief or non-existent schooling, and lack of solid employment. In that way, they are complicit in the project of hegemonic masculinity, achieving some measure of it in the short term; in the end, however, they are subordinated by the very ideal for which they strive. Despite the initial gender status rewards granted to Sasak boys for marrying young, their early marriages work to confine them, their wives and their children, to the inter-generational cycle of pervasive poverty and marginalisation that characterises rural north Lombok.

\section{NOTES}

${ }^{1}$ In the United Nations Convention on the Rights of the Child (UNCRC), a child is defined as a person below the age of 18 .

${ }^{2}$ A child born prior to the isbath nikah is considered born out of wedlock. The child is deemed to have civil law relations only with its mother and only her name will be on the birth certificate. While it is legally possible for the father to apply for legal recognition of paternity following the registration of the child's birth, this is an expensive and convoluted process requiring DNA testing, official statements from witnesses and court-approval. Even if successful, the father's name will be added to the child's birth certificate as a mere side notation, resulting in a birth certificate that looks - and is looked upon - differently to that of a child whose parents were married under state law. The complexity and expense of this process, together with the stigma and discrimination towards children born out of wedlock, are strong disincentives for Sasak couples in unregistered marriages to register the births of their children or, indeed, to register their marriage. 


\section{DAFTAR PUSTAKA}

Abdullah, Idris, and Djumardin. 2017. "Legal Protection Setting of Post-Divorce Women's Rights: Case Study of Siri Marriage in Lombok." Mediterranean Journal of Social Sciences 8(3):297-303.

Bartholomew, John R. 2001. Alif Lam Mim, Kearifan Masyarakat Sasak. Yogyakarta: Tiara Wacana.

Bennett, Linda R. 2005. Women, Islam and Modernity: Single Women, Sexuality and Reproductive Health in Contemporary Indonesia. Oxford: Routledge Curzon.

Bennett, Linda R. 2014. "Early Marriage, Adolescent Motherhood, and Reproductive Rights." Wacana 15(1):66-86.

Bennett, Linda R. 2015. "Young Sasak Mothers - 'Tidak Manja Lagi': Transitioning from Single Daughter to Young Married Mother in Lombok, Eastern Indonesia," pp. 238-261. In Katherine Robinson (ed) Youth Identities and Social Transformations in Modern Indonesia. Leiden/Boston: Brill.

Beta, Annisa, R and Ryan Febrianto. 2020. "Are Indonesian Girls Okay? An Examination Of The Discourse Of Child Marriage, Victimization, And Humanitarian Visuality Of Global South Girls". Jurnal Studi Pemuda, 9(2).

BPS. 2013. Kabupaten Lombok Utara Dalam Angka Tahun 2013. Badan Pusat Statistik Lombok Utara, 52085.12.01.

Brown, Colin. 2003. A Short History of Indonesia: The Unlikely Nation? Crows Nest: Allen \& Unwin.

Buttenheim, Alison and Jenna Nobles. 2009. "Ethnic Diversity, Traditional Norms, and Marriage Behaviour in Indonesia." Population Studies 63(3): 277-294.

Clark, Marshall A. 2004. "Men, Masculinities and Symbolic Violence in Recent Indonesian Cinema." Journal of Southeast Asian Studies, 35: $113-131$.

Clark, Marshall A. 2010. Maskulinitas: Culture, Gender and Politics in Indonesia. Melbourne: Monash University Press.
Clegg, Kendra 2004. "Ampenan: Conceptions of Nationality, Ethnicity, and Identity in Urban Lombok". PhD dissertation. Deakin University, Burwood.

Connell, Raewyn. 1987. Gender and power. Sydney: Allen and Unwin.

Connell, Raewyn and James W. Messerschmidt. 2005. "Hegemonic masculinity: Rethinking the concept." Gender \& society, 19(6): 829859.

Dowd, Nancy. 2010. The Man Question: Male Subordination and Privilege. New York: New York University Press.

Elmhirst, Rebecca. 2007. "Tigers and Gangsters: Masculinities and Feminised Migration in Indonesia." Population, Space and Place 13: 225-238.

Giddens, Anthony 1991. Modernity and Self-identity: Self and Society in the Late Modern Age. Stanford: Stanford University Press.

Grace, Jocelyn. 2004. "Sasak Women Negotiating Marriage, Polygyny and Divorce in Rural East Lombok." Intersections: Gender, History and Culture in the Asian Context 10. Retrieved March 29, 2020 (http://intersections.anu. edu.au/issue10/grace.html)

Grace, Jocelyn. 2006. "'Lacking Education": Young Sasak women and Teenage Marriage, Divorce and Polygamy in Rural East Lombok." Paper presented at the Biennial Asian Studies Association of Australia Conference, La Trobe University, Melbourne, July 8-11, 2006.

Hay, M. Cameron. 2007. Remembering to Live: Illness at the Intersection of Anxiety and Knowledge in Rural Indonesia. Ann Arbor: University of Michigan Press.

Heelas, Paul, Scott Lash and Paul Morris. 1996. Detraditionalization: Critical Reflections on Authority and Identity. Cambridge: Blackwell. Izharuddin, Alicia. 2017. Gender and Islam in Indonesian Cinema. London: Palgrave Macmillan.

Jones, Gavin W. 2002. "The Changing Indonesian Household," pp. 219-234. In Katherine Robinson and Sharon Bessell (eds) Women in Indonesia: Gender, Equity and Development. Singapore: Institute of Southeast Asian Studies. 
Kamsma, Theo and Karin Bras. 2000. "Gili Trawangan - From Desert Island to 'Marginal' Paradise: Local Participation, Small-scale Entrepreneurs and Outside Investors in an Indonesian Tourist Destination," pp. 170-184. In Greg Richards and Derek Hall (eds) Tourism and Sustainable Community Development. London: Routledge.

Krufield, Ruth. 1966. "Fatalism in Indonesia: A Comparison of Socio-Religious Types on Lombok." Anthropological Quarterly 39(3):180-190.

Lestari, Dewi M. 2001. "Beberapa Faktor Yang Mempengaruhi Remaja Putri Mempertahankan Kehamilan Pra Nikah." PhD dissertation. University of Indonesia, Depok.

Liamputtong, Pranee. 2019. Qualitative Research Methods, Fifth Edition. Oxford: Oxford University Press.

Mansfield, Harvey G. 2006. Manliness. New Haven: Yale University Press.

Marshan, Joseph N., M. Fajar Rakhmadi and Mayang Rizky. 2013. "Prevalence of Child Marriage and Its Determinants among Young Women in Indonesia." Paper presented at the Child Poverty and Social Protection Conference, 10 September 2013. Retrieved March 29, 2020 (https://www.neliti.com/publications/605/prevalence-of-child-marriage-andits-determinants-among-young-women-in-indonesia)

Messerschmidt, James W. 2018. Hegemonic Masculinity: Formulation, Reformulation, and Amplification. Lanham: Rowman \& Littlefield.

Naafs, Suzanne. 2013. "Youth, Gender, and the Workplace: Shifting Opportunities and Aspirations in an Indonesian Industrial Town." Annals of the American Academy of Political and Social Science 646:233-250.

Nilan, Pam. 2008. "Youth Transitions to Urban, Middle-class Marriage in Indonesia: Faith, Family and Finances." Journal of Youth Studies 11(1):65-82.
Nilan, Pam. 2009. "Contemporary Masculinities and Young Men in Indonesia." Indonesia and the Malay World 37(109): 327-344.

Nilan, Pam, Argyo Demartoto and Agung Wibowo. 2013. "Youthful Warrior Masculinities in Indonesia," pp. 69-84. In Joseph Gelfer (ed) Masculinities in a Global Era. Dordrecht: Springer International.

Nurlaewati, Euis. 2010. Modernization, Tradition and Identity: The Kompilasi Hukum Islam and Legal Practice in the Indonesian Religious Courts. Amsterdam: Amsterdam University Press.

Parker, Lyn. 2008. "To Cover the Aurat: Veiling, Sexual Morality and Agency among the Muslim Minangkabau, Indonesia." Intersections: Gender and Sexuality in Asia and the Pacific 16:5-20.

Platt, Maria. 2012. "Married Men Behaving Badly: Islam, Gender and Extramarital Relationships in Eastern Indonesia." Intersections: Gender and Sexuality in Asia and the Pacific 28. Retrieved March 29, 2020 (http://intersections. anu.edu.au/issue28/platt.htm)

Platt, Maria. 2017. Marriage, Gender and Islam in Indonesia: Women Negotiating Informal Marriage, Divorce and Desire. New York: Routledge.

Qibthiyyah, Riatu and Ariane J. Utomo. 2016. "Family Matters: Demographic Change and Social Spending in Indonesia." Bulletin of Indonesian Economic Studies 52(2): 133-159.

Ricklefs, Merle. 1993. A History of Modern Indonesia Since c.1300. London: MacMillan Press.

Rumble, Lauren, Amber Peterman, Nadira Irdiana, Margaret Triyana and Emilie Minnick. 2018. "An Empirical Exploration of Female Child Marriage Determinants in Indonesia." $B M C$ Public Health 18(407):1-13.

Scherer, Savitri. 2006. "Tuna karya, jilbab and cow-boy hat: Youth in Suharto's Indonesia as reflected in the works of Remy Sylado and Emha Ainun Nadjib." Indonesia and the Malay World, 34(99): 197-211. 
Smith, Bianca. 2014. "Stealing Women, Stealing Men: Co-creating Cultures of Polygamy in a Pesantren Community in Eastern Indonesia." Journal of International Women's Studies, 15(1): 118-135.

Sukmayeti, Evi. 2019. "Meraqiq, Awig-awig and Child Marriage in Sasak Labuapi," pp. 199 218. In Mies Grijns, Hoko Horii, Sulistyowati Irianto and Pinky Saptandari (eds) Marrying Young in Indonesia: Voices, Laws and Practices. Jakarta: Yayasan Pustaka Obor Indonesia.

Suryadarma, Daniel, Asep Suryahadi and Sudarno Sumarto. 2006. Causes of Low Secondary School Enrolment in Indonesia. Jakarta: SMERU.

Townsend, Nicholas. 2002. Package Deal: Marriage, Work and Fatherhood in Men's Lives. Philadelphia: Temple University Press.

Utomo, Ariane, Anna Reimondos, Iwu Utomo, Peter McDonald and Terence Hull. 2014. "What Happens After You Drop Out? Transition to Adulthood among Early School-leavers in Urban Indonesia." Demographic Research 30(41):1189-1218.

Van der Kraan, Alphonse. 1975. "The Nature of Balinese Rule in Lombok: Pre-colonial State Systems," pp. 91-107. In Anthony Reid and Lance Castles (eds) South East Asia: The Malay Peninsula, Sumatra, Bali-Lombok, South Celebes. Kuala Lumpur: Council of the Malaysian Branch of the Royal Asiatic Society.
Vickers, Adrian. 2005. A History of Modern Indonesia. Cambridge: CUP.

Widyoningsih 2011. "Pengalaman Keluarga Merawat Anak Remaja Dengan Kehamilan'Ttidak Diinginkan (KTD) di Kabupaten Cilacap, Provinsi Jawa Tengah: Studi Fenomenologi." PhD dissertation. University of Indonesia, Depok.

Wilson, Ian. 2012. "The 'Biggest Cock': Masculinity, Violence and Authority amongst Jakarta's Gangs,", pp. 121-138. In Lenore Lyons and Michele Ford (eds) Men and Masculinities in Southeast Asia. London: Routledge.

WFP. 2013. Brief Profile of Nusa Tenggara Timur Province, Indonesia and a Glance of WFP Indonesia Programmes Within the Province. Retrieved June 30, 2017 (https://www.wfp.org/ sites/default/files/NTB\%20Factsheet\%20 ENG\%2012oct12.pdf) 
